\title{
Long term efficacy of DOTS regimens for tuberculosis: systematic review
}

\author{
Helen S Cox, PhD scholar, Martha Morrow, research coordinator, Peter W Deutschmann, executive director
}

Australian International Health Institute, University of Melbourne, Carlton, VIC 3010, Melbourne, Australia

Correspondence to: H S Cox, Macfarlane Burnet Institute for Medical Research and Public Health, Melbourne, VIC 3004, Australia hcox@burnet.edu.au

doi:10.1136/bmj.39463.640787.BE

\section{ABSTRACT}

Objective To identify published studies assessing tuberculosis recurrence after successful treatment with standard short course regimens for six months to determine the strength and sufficiency of evidence to support current guidelines.

Design Systematic review.

Data sources Medline, Embase, Cochrane clinical trials register, specialist tuberculosis journals, and reference lists. Only English language publications were eligible. Review methods Studies were included irrespective of methodology or quality. Abstracted information included inclusion and exclusion criteria for participants, duration of follow-up, and definitions of treatment success and disease recurrence. The primary outcome was the proportion of successfully treated patients recorded with recurrent tuberculosis during the follow-up period.

Results 17 study arms from 16 studies met the inclusion criteria; 10 were controlled clinical trials and six were either studies done under programmatic conditions or observational studies from functioning tuberculosis programmes. Although several clinical trials supported the use of daily treatment regimens, studies reporting tuberculosis recurrence after intermittent regimens were limited. Few studies carried out under routine programmatic conditions reported disease recurrence. Overall there was wide variation in recurrence after successful treatment, ranging from $0 \%$ to $14 \%$. Considerable heterogeneity across studies precluded the systematic assessment of factors contributing to tuberculosis recurrence.

Conclusions Despite DOTS (directly observed treatment, short course) being implemented for more than 10 years and millions of patients treated for tuberculosis, few studies have assessed the ability of standard DOTS regimens to result in lasting cure for patients treated under routine programmatic conditions.

\section{INTRODUCTION}

The DOTS (directly observed treatment, short course) strategy for tuberculosis control was launched by the World Health Organization in $1995 .^{1}$ The strategy, although based around short course treatment regimens for a minimum of six months, also includes tenets such as political commitment, good management practices, sputum smear microscopy for diagnosis, and the direct observation of doses to ensure adherence. To date DOTS remains the cornerstone of global efforts at tuberculosis control. ${ }^{2}$ Before the implementation of DOTS, tuberculosis treatment in many resource poor settings was chaotic, non-standardised, and poorly monitored and consequently had little epidemiological impact on the incidence of tuberculosis. ${ }^{3}$ The introduction of the DOTS strategy encompassing standardised regimens for six months through directly observed treatment has led to improvements in treatment outcomes for many patients.

By 2005, 187 countries were implementing DOTS, with 4.9 million cases of tuberculosis treated under the strategy in that year alone. ${ }^{4} \mathrm{WHO}$ reports that $84 \%$ of new (previously untreated) patients registered with DOTS worldwide in 2004 were "successfully treated." Despite this apparent achievement, the incidence of tuberculosis continues to increase in many parts of the world, albeit at a lower rate of increase, and has not fallen in some countries that have achieved "good" results as measured under DOTS..$^{4-6}$

Treatment success under DOTS concerns two outcomes - cured and treatment completed. Patients are classified as cured if they finish the treatment regimen with negative sputum bacteriology (most commonly sputum smear microscopy) at the end of treatment, whereas those adjudged as treatment completed have finished the regimen in full without showing evidence of treatment failure and without negative bacteriology. Despite being assessed as cured, patients can develop recurrent disease some time after completing treatment. This was thought to be caused solely by relapse of the same infection. Although we now know that reinfection with a different strain of Mycobacterium tuberculosis is an important cause of tuberculosis recurrence, ${ }^{78}$ recurrent disease is still considered to be an important measure of the efficacy of tuberculosis treatment; it also has a major impact on patients.

High rates of tuberculosis recurrence have been observed recently among patients reported as successfully treated within a DOTS programme in Uzbekistan, a former Soviet republic in Central Asia. ${ }^{\mathrm{w} 7}$ Only sixty five per cent of all successfully treated patients were still alive and also free of a rediagnosis of active tuberculosis 18 months after seeming to successfully finish treatment. Although drug resistance is extremely high in 
this region and contributed significantly to disease recurrence and mortality in the study population, recurrence and mortality were also high $(22 \%)$ among the small subgroup initially diagnosed as new patients with pan susceptible strains of tuberculosis, and seemingly successfully treated with the recommended DOTS regimen. The high recurrence rates in Uzbekistan prompted us to question whether the standard chemotherapy regimens for six months recommended through the DOTS strategy can be relied on for lasting cure in individual patients. We therefore carried out a systematic review of studies assessing tuberculosis recurrence after successful treatment with standard short course regimens for six months to determine the strength and sufficiency of evidence to support current guidelines.

\section{METHODS}

The treatment of tuberculosis as recommended in the DOTS strategy is characterised by a standardised approach to drug combinations, intermittency, and time frames, largely relying on short course regimens for six months. The DOTS guidelines recommend a short course regimen for newly diagnosed patients whose sputum shows smear positive results, which starts with an intensive phase of four drugs (isoniazid, rifampicin, pyrazinamide, and ethambutol) for two months, followed by a continuation phase of rifampicin and isoniazid for four months, all given under direct observation of treatment. When direct observation is not feasible throughout the treatment period, the DOTS strategy recommends a continuation phase for six months - that is, a total of eight months' treatment - with self administered ethambutol and isoniazid but states that this regimen is less efficacious owing to high relapse. ${ }^{910}$

Under DOTS, treatment may be given either daily or three times weekly for both treatment phases. Additionally, in the intensive phase ethambutol may be replaced by the injectable streptomycin. ${ }^{9}$ The various potential alternatives for treatments that last six months translate into a total of eight different regimens. Two may be omitted from consideration on the assumption that programmes are highly unlikely to adopt an intermittent intensive phase followed by a daily continuation phase. Hence we focus on tuberculosis recurrence among patients successfully treated with any of the six short course regimens for six months recommended under DOTS (see table 2).

\section{Search strategy}

We did a comprehensive search of the published English language literature to identify studies that utilised any of the six regimens (regardless of dose) for the treatment of pulmonary tuberculosis, and determined rates of recurrent disease after treatment. We included retrospective and prospective studies and those with active or passive follow-up of patients. Apart from the specific reporting of disease recurrence by particular treatment regimen we applied no other criteria for the inclusion of studies. We searched three electronic databases: PubMed (1950-December 2006), Embase (1974-December 2006), and the Cochrane Library controlled trials register. We used combinations of several terms for the search strategy: "tuberculosis", "therapy", "treatment regimen", "DOTS", "recurrence", "relapse", "treatment outcome", "rifampicin", and "isoniazid". We manually searched the International Journal of Tuberculosis and Lung Disease, along with its precursors Tubercle, Tubercle and Lung Disease, and the Bulletin of the International Union Against Tuberculosis and Lung Disease. Additional studies were identified through back tracing of reference lists and subsequent reports from the same longitudinal studies.

\section{Data extraction and quality assessment}

From the publications we abstracted information on treatment regimen, study design, country, year of patient enrolment, sample size, inclusion and exclusion criteria for participants, duration of follow-up, HIV testing, testing of susceptibility to tuberculosis drugs, definitions of treatment success and recurrence, measures taken to maximise adherence, default rate during treatment, and whether recurrences were differentiated into those caused by relapse or those caused by reinfection.

For the assessment of disease recurrence we abstracted data, when possible, according to the following criteria: new tuberculosis (defined variably as no previous treatment for tuberculosis, or less than 2-4 weeks of previous treatment); HIV negative; drug susceptible tuberculosis (or without multidrug resistant tuberculosis); and bacteriological confirmation of treatment success. The primary outcome measure was the proportion of successfully treated patients who developed recurrent tuberculosis during the follow-up period. No criteria were applied for the definition of recurrent tuberculosis.

We used the exact binomial method to calculate confidence intervals for tuberculosis recurrence. Owing to the range of treatment regimens included and the considerable heterogeneity in study variables we did not carry out a meta-analysis of tuberculosis recurrence across the included studies.

We assessed methodological quality across two domains. Firstly, we assessed the quality of the initial tuberculosis treatment episode through reported measures to ensure adherence and through default from treatment. Secondly, we assessed adequacy of followup to ascertain tuberculosis recurrence by the type of method used to trace patients (active or passive detection of recurrent disease episodes) and by the proportion of patients excluded from the follow-up analysis for any reason. Studies were classified as high, average, or poor in each domain according to several criteria (see box). As several of the included studies were done several decades ago, we did not consider it feasible to contact authors for missing information. 
Criteria for determining methodological quality of included studies

\section{Quality of tuberculosis treatment}

High—significant measures taken to ensure or monitor treatment adherence; $८$ \% default from treatment

Average—standard adherence measures, including direct observation of doses; $८ 10 \%$ default from treatment

Poor-standard adherence measures or not stated; $>10 \%$ default from treatment or default not given

Quality of assessment of tuberculosis recurrence (follow-up)

High-active follow-up of patients (more than one patient contact within first year); $८ 10 \%$ of successfully treated patients excluded from analysis (for any reason)

Average-single point assessment of recurrence (active) or ongoing routine surveillance of rediagnosis (passive); «10\% of successfully treated patients excluded from analysis (for any reason)

Poor-active or passive follow-up of patients; $>10 \%$ of successfully treated patients excluded from analysis (for any reason) functioning DOTS programmes in India, ${ }^{\text {w9-w11 }}$ and our recent observational study from Uzbekistan. ${ }^{\mathrm{w} 7}$ Although at least one study arm was located for each of five of the recommended regimens, only the Uzbekistan study investigated the commonly used regimen containing ethambutol with an intermittent continuation phase.

\section{Tuberculosis recurrence}

Levels of disease recurrence after successful treatment ranged from $0 \%$ in a small controlled clinical trial in Singapore $^{\text {w21 w22 }}$ to $14 \%$ among miners in South Africa $^{\text {w5 }}{ }^{6}$ (fig 2 and table 2). The South African study was the only study that differentiated between relapse and reinfection as the cause of tuberculosis recurrence. Among HIV negative cases, 94\% of recurrent episodes were attributed to relapse, whereas reinfection was more likely among HIV positive cases. In addition to the Uzbekistan and South African studies, high rates of recurrence were also seen in the observational studies carried out within DOTS programmes in India, a country that has adopted a fully intermittent treatment regimen. Two of these studies reported recurrence of more than $10 \%$. $^{\text {w10 w11 }}$

\section{Key differences between included studies}

The quality of tuberculosis treatment according to the chosen indicators varied substantially across studies (tables 1 and 2). Although not definitive, there was a tendency for higher recurrence rates among studies rated as poor for tuberculosis treatment (fig 2). In addition to variations in quality, a high degree of heterogeneity was also found in other key factors among the included studies, including differences between the types of patients initially enrolled and then excluded from the analysis of recurrence. Many of the clinical trials restricted enrolment, excluding and those who developed recurrent disease after successful treatment. ${ }^{1011}$ The third study was excluded on the basis that recurrence, although reported overall, was not reported after treatment success. ${ }^{12}$ An additional study arm in one study ${ }^{\text {w21 } 22}$ was excluded because, although the regimen was one of those currently recommended, drugs were given as a combined formulation and there were doubts as to the adequacy of the dose of some drugs. ${ }^{13}$ It was decided to include one Indian study despite the lack of a detailed description of the treatment regimen, as it could be assumed that the regimen used followed the national DOTS guidelines. ${ }^{\text {w9 }}$

\section{Study characteristics}

Table 1 summarises the 16 studies (17 study arms) included in the review. ${ }^{\text {w1-w26 }}$ Nine were controlled clinical trials (with or without randomisation of regimens), whereas one was a prospective trial done under conditions approximating those found in routine programmes. ${ }^{\mathrm{w} 17}$ The remaining six were observational studies, one from the pre-DOTS tuberculosis programme in China, ${ }^{\text {w23 }}$ one describing a cohort of miners in South Africa, ${ }^{\text {w5 w6 }}$ three more recent studies from 


\section{Table 1 |Characteristics of included studies}

Study location (year of diagnosis)
Britain (1979) ${ }^{\text {w1-w3 }}$
Study design

Controlled clinical trial
Patients

New, culture positive patients
Concomitant illnesses (renal or hepatic dysfunction, gout, impaired vision), pregnancy, others not stated

Concomitant disease, poor immune function, poor renal or hepatic function, malignancies, depression, pregnancy

and Thailand (year clinical trial patients

not given) ${ }^{\mathrm{w} 4}$

\begin{tabular}{llll}
\hline $\begin{array}{l}\text { South Africa } \\
(1995)^{\mathrm{w} 5 \mathrm{w} 6}\end{array}$ & $\begin{array}{l}\text { Observational study } \\
\text { (programme conditions) }\end{array}$ & $\begin{array}{l}\text { New and previously treated, culture } \\
\text { positive patients }\end{array}$ & None reported
\end{tabular}

Exclusions and changes to treatment

Measures to ensure adherence; default from treatment

Adherence measures not stated; $3 \% \quad$ Hig

default, $97 \%$ adherence among those

completing treatment (urine isoniazid metabolites)

Admission to hospital for first month of Poor

treatment, otherwise self

administered; $12 \%$ default

Direct observation by healthcare staff; Poor

default not given, $25 \%$ reported to

have missed directly observed therapy (no criteria given for "missed")

\begin{tabular}{llll}
\hline $\begin{array}{l}\text { Uzbekistan (2001- } \\
\text { 2) }\end{array}$ & $\begin{array}{l}\text { Observational study } \\
\text { (programme conditions) }\end{array}$ & $\begin{array}{l}\text { New and previously treated, smear } \\
\text { positive patients }\end{array}$ & $\begin{array}{l}\text { Treatment extended if smear positive } \\
\text { at end of intensive phase }\end{array}$
\end{tabular}

Direct observation by healthcare staff; Poor patients admitted to hospital for intensive phase; $17 \%$ default ( $8 \%$ among new cases)

Haiti (1990-2) ${ }^{\text {w8 }} \quad$ Controlled clinical trial

New patients, with clinical diagnosis of tuberculosis

Rural patients-treatment extended to account for interruptions outreach workers assigned to each
Quality rating (tuberculosis treatment)

Direct observation by healthcare staff; Average patient to ensure adherence; $8 \%$ default, $98 \%$ of doses taken by patients completing treatment

\begin{tabular}{llll}
\hline India $(1996-8)^{\text {w9 }}$ & $\begin{array}{l}\text { Observational study } \\
\text { (programme conditions) }\end{array}$ & New and previously treated patients & None reported \\
\hline India (1999) ${ }^{\text {w10 }}$ & $\begin{array}{l}\text { Observational study } \\
\text { (programme conditions) }\end{array}$ & $\begin{array}{l}\text { New, smear and culture positive } \\
\text { patients }\end{array}$ & None reported \\
\hline India $(2000-1)^{\text {w111 }}$ & $\begin{array}{l}\text { Observational study } \\
\text { (programme conditions) }\end{array}$ & New, smear positive patients & $\begin{array}{l}\text { Treatment extended to account for } \\
\text { interruptions }\end{array}$
\end{tabular}

Direct observation by healthcare staff; Average $9 \%$ default

Direct observation by healthcare staff; Poor $25 \%$ default

Direct observation by healthcare staff; Poor $16 \%$ default, $30 \%$ took more than nine months to complete six months' regimen

\begin{tabular}{|c|c|c|c|}
\hline $\begin{array}{l}\text { Singapore } \\
(1975-7)^{w 12 w 14}\end{array}$ & $\begin{array}{l}\text { Randomised controlled } \\
\text { clinical trial }\end{array}$ & $\begin{array}{l}\text { New, smear and culture positive } \\
\text { patients }\end{array}$ & Concomitant psy \\
\hline $\begin{array}{l}\text { Kenya, Tanzania, } \\
\text { Uganda, and } \\
\text { Zambia (1978- } \\
80)^{\text {w15 w16 }}\end{array}$ & $\begin{array}{l}\text { Randomised controlled } \\
\text { clinical trial }\end{array}$ & $\begin{array}{l}\text { New, smear and culture positive } \\
\text { patients with tuberculosis of recent } \\
\text { origin }\end{array}$ & tuberculosis, \\
\hline $\begin{array}{l}\text { urkina Faso } \\
1988-90)^{\mathrm{w} 17}\end{array}$ & $\begin{array}{l}\text { Prospective study } \\
\text { (programme conditions) }\end{array}$ & $\begin{array}{l}\text { New and previously treated patients } \\
\text { (bacteriology irrelevant) }\end{array}$ & No \\
\hline
\end{tabular}

Direct observation by healthcare staff; Average $5 \%$ default

Patients admitted to hospital High

throughout treatment; $1.5 \%$ default

Direct observation by healthcare staff, Poor

active defaulter tracing, patients

admitted to hospital for intensive

phase; $17 \%$ combined default and loss to follow-up

Patients admitted to hospital for Poor

intensive phase; $12 \%$ default be pregnancy, early default from tuberculosis treatment-treatment extended to account for interruptions

\begin{tabular}{|c|c|c|c|c|c|}
\hline $\begin{array}{l}\text { Singapore } \\
(1979-81)^{\mathrm{w} 19} \text { w20 }\end{array}$ & $\begin{array}{l}\text { Randomised controlled } \\
\text { clinical trial }\end{array}$ & $\begin{array}{l}\text { New, smear and culture positive } \\
\text { patients }\end{array}$ & $\begin{array}{l}\text { Patients missing drug susceptibility } \\
\text { results, patients in whom therapy was } \\
\text { changed or missed owing to toxicity }\end{array}$ & $\begin{array}{l}\text { Direct observation by healthcare staff; } \\
1.3 \% \text { default }\end{array}$ & Average \\
\hline $\begin{array}{l}\text { Singapore (1983- } \\
\text { 7) }{ }^{\mathrm{w} 21 \mathrm{w} 22}\end{array}$ & $\begin{array}{l}\text { Randomised controlled } \\
\text { clinical trial }\end{array}$ & $\begin{array}{l}\text { New, smear and culture positive } \\
\text { patients }\end{array}$ & Reasons for exclusion not stated & $\begin{array}{l}\text { Direct observation by healthcare staff; } \\
6 \% \text { default }\end{array}$ & Average \\
\hline China $(1991)^{\mathrm{w} 23}$ & $\begin{array}{l}\text { Observational study } \\
\text { (programme conditions) }\end{array}$ & $\begin{array}{l}\text { New and previously treated, smear } \\
\text { positive patients }\end{array}$ & $\begin{array}{l}\text { Treatment extended if smear positive } \\
\text { at end of intensive phase }\end{array}$ & $\begin{array}{l}\text { Direct observation by healthcare staff; } \\
0.3 \% \text { default }\end{array}$ & Average \\
\hline $\begin{array}{l}\text { Hong Kong } \\
(1991-5)^{\text {w24-w26 }}\end{array}$ & $\begin{array}{l}\text { Randomised controlled } \\
\text { clinical trial }\end{array}$ & New, culture positive patients & $\begin{array}{l}\text { Concomitant extrapulmonary } \\
\text { tuberculosis or large pleural effusion, } \\
\text { poor general condition, serious non- } \\
\text { tuberculosis disease, drug addicts, } \\
\text { early deaths while receiving treatment } \\
\text {-treatment extended to account for } \\
\text { interruptions }\end{array}$ & $\begin{array}{l}\text { Direct observation by healthcare staff; } \\
2 \% \text { default }\end{array}$ & Average \\
\hline
\end{tabular}

patients in poor clinical condition or with concomitant diseases, variously described as "serious non-tuberculous disease," renal or hepatic dysfunction, poor immune function, drug addiction, and extrapulmonary tuberculosis (table 1). In addition, some clinical trials recruited only patients who were more easily accessible, excluding those in rural areas. In several of the clinical trials a tighter definition of default was used to exclude patients from the analysis of recurrence than is commonly used in the DOTS strategy (table 2). Under 


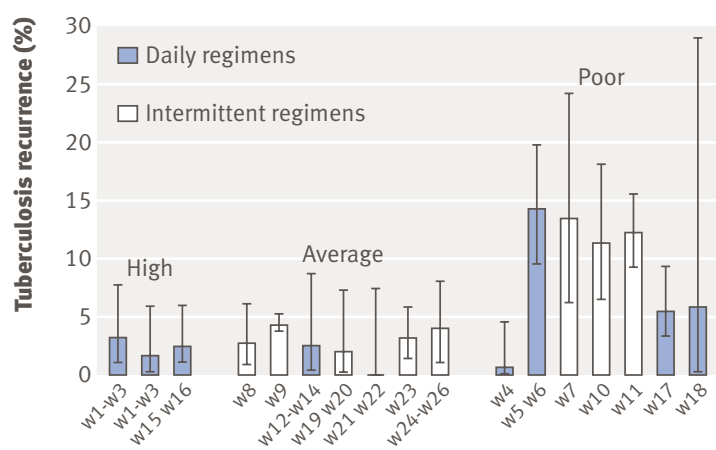

Study reference

Fig 2 Tuberculosis recurrence after successful treatment (with $95 \%$ confidence intervals), divided by quality rating for treatment

the DOTS strategy, default is defined as treatment interruption for two consecutive months or more ${ }^{9}$; by contrast, these clinical trials considered patients to have defaulted if they missed one or more drugs for at least two weeks during the intensive phase, or across six weeks overall.

Variations in measurement and reporting on two important factors-HIV infection and the extent of resistance to tuberculosis drugs - were also found in this review. Attempts were made to negate the potential influence of both factors by abstracting recurrence for HIV negative patients or those infected with drug susceptible strains when these data were given. Despite this, in several study arms these factors were not measured or not adequately reported on (table 2). Key differences also existed in definitions of treatment success; in general, the clinical trials defined success as bacteriological cure (either sputum smear or culture), whereas many of the observational studies relied on the DOTS definition of treatment success, which includes patients who complete treatment without bacteriological confirmation of cure (table 2).

Adequacy of assessment of tuberculosis recurrence also varied across study arms; five studies were rated as poor primarily because a high proportion of patients was excluded from the analysis of recurrence (table 2). The impact of this exclusion is unclear, although studies relying on passive detection of recurrent tuberculosis are more likely to under-report recurrence compared with studies using active follow-up of patients. The definition of recurrence also varied across study arms, ranging from a strict standard of at least two positive cultures (of at least 5-10 colonies) at least a month apart and within a three month period, to a clinical diagnosis of tuberculosis, with or without bacteriological confirmation (as per routine practice; table 2). Finally, the extent to which deaths were excluded or could be attributed to recurrent disease was also variably assessed, as was the duration of follow-up after completion of treatment (table 2).

\section{DISCUSSION}

This review was prompted by a finding of high tuberculosis recurrence after successful treatment from a functioning DOTS programme utilising a recommended short course treatment regimen for six months. ${ }^{\text {w7 }}$ We assessed whether evidence is sufficient that the recommended treatment regimens promoted through the DOTS strategy result in lasting cure. We located several controlled clinical trials that show the effectiveness of daily short course regimens under trial conditions, but found few that report on tuberculosis recurrence after the recommended intermittent treatment regimens. Only a handful of assessments of posttreatment or longer term outcomes from functioning DOTS programmes was found. Given that more than a decade has elapsed since the start of DOTS implementation and that millions of people have been treated under DOTS, the lack of published data on the longer term efficacy of the recommended treatment regimens under programmatic conditions is both surprising and concerning.

\section{Potential contributors to tuberculosis recurrence}

In addition to the overall dearth of data, a large degree of variation was found in tuberculosis recurrence across the included studies, ranging from $0 \%$ to $14 \%$. Several factors might explain this large variation. The studies varied not just in quality and treatment regimen used, but also in terms of inclusion and exclusion criteria, the presence of concomitant diseases (including HIV infection and tuberculosis drug resistance), and definitions of treatment success and tuberculosis recurrence. Given the noticeable differences in key criteria between the included studies it was not possible to carry out a meta-analysis to assess the influence of individual factors on recurrence. None the less, the observed differences in recurrence may well be explained by the key factors of daily compared with intermittent treatment, the characteristics of patients included in studies, and poor treatment adherence resulting from the difficulties of direct observation of doses.

The DOTS guidelines state that "isoniazid, rifampicin, pyrazinamide and streptomycin are all as efficacious when given three times weekly as when given daily."9 The Cochrane database of systematic reviews, however, concludes that evidence for this is insufficient, with only one study fulfilling their selection criteria. ${ }^{14}$ A more recent large case-control study from Hong Kong found intermittent (three times weekly) treatment to be significantly associated with recurrence when compared with daily treatment, whereas prolongation of treatment was protective. ${ }^{15}$ Total duration of treatment was a significant independent predictor of recurrence in a separate large meta-analysis assessing the effect of HIV infection on tuberculosis recurrence. ${ }^{16}$ The Hong Kong study also found that cavitation and extensive disease were independently associated with recurrence. ${ }^{15}$ In an accompanying editorial, the authors suggested that the extent of 


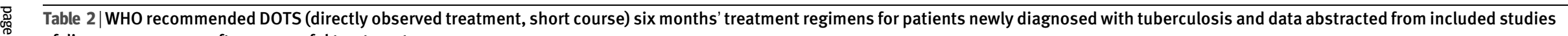
$\sigma$ of disease recurrence after successful treatment

\section{DOTS regimen,}

study

Daily regimen with

ethambutolt:

British Thoracic

Society ${ }^{\text {w1-w3 }}$

New, negative culture at treatment end; not
tested for HIV; not tested for drug susceptibility

Death, prolonged
treatment, and

lost to follow-up

Reasons for
exclusion from

exclusion from

analysis

No (\%) of patients
assessed for
recurrence

No, $\%(95 \% \mathrm{Cl})$ of

patients with

recurrent
tuberculosis)
Assessment and definition of recurrence

Duration of

follow-up after

treatment (range)

\begin{tabular}{|c|c|c|c|c|c|c|c|c|}
\hline & & & & & & & & \\
\hline $\begin{array}{l}\text { Gonzalez-Montaner } \\
\text { et al }{ }^{\text {w }}\end{array}$ & $\begin{array}{l}\text { New, negative bacteriology at treatment end; } \\
\text { HIV negative; not tested for drug susceptibility }\end{array}$ & 153 & $\begin{array}{l}\text { Death and lost to } \\
\text { follow-up }\end{array}$ & $119(78)$ & $1,0.8(0.0$ to 4.6$)$ & $\begin{array}{l}\text { Patients seen every } 6 \text { months; } 2 \text { successive } \\
\text { positive cultures }\end{array}$ & 24 months & Poor \\
\hline $\begin{array}{l}\text { Sonnenberg et } \\
\text { al, }{ }^{\mathrm{w} 5} \text { Murray et al }{ }^{\mathrm{w} 6}\end{array}$ & $\begin{array}{l}\text { New and previously treated patients; negative } \\
\text { culture or unable to produce sputum at } \\
\text { treatment end; HIV negative; not tested for } \\
\text { drug susceptibility }\end{array}$ & 175 & Lost to follow-up & $169(97)$ & $\begin{array}{c}24,14.2(9.0 \text { to } \\
19.7)\end{array}$ & $\begin{array}{l}\text { Patients seen at } 3 \text { and } 6 \text { months, thereafter } \\
\text { monitored by routine tuberculosis } \\
\text { surveillance; positive culture and symptomatic } \\
\text { for tuberculosis; deaths not considered } \\
\text { recurrence }\end{array}$ & $\begin{array}{c}\text { Mean } 29 . \\
5 \text { months (17.8- } \\
35.2)\end{array}$ & High \\
\hline
\end{tabular}

Intermittent

continuation phase

regimen with

ethambutolł:

Cox et al ${ }^{\text {w7 }}$

New, DOTS treatment success; cases of

multidrug resistant tuberculosis excluded; not

71

Lost to follow-up

$67(94)$

9, 13.4 (6.3 to

Retrospective review of tuberculosis registers

Median 16 months Average

tested for HIV

24.0)

and clinical records; positive sputum smear;

deaths without positive smear not conside

(13-21)

recurrence

Intermitten

regimen with

ethambutol§:

Chaisson et alws

New, DOTS treatment success; HIV negative;

$212 \quad$ None

one

6, $2.8(1.0$ to 6.1$)$

Monthly contact by outreach workers and clinical assessment every 6 months; clinical diagnosis of tuberculosis with or without bacteriology; deaths not considered

diagnosis of
bacteriologs;
recurrence

Dholakia et al ${ }^{\text {w9 }}$ New, DOTS treatment success; HIV not

$1483 \quad$ Non

$1483(100)$

63, 4.3 (3.3 to 5.4)

Current and previous health status assessed

reported; not tested for drug susceptibility

single patient interview (or family); stated as

relapse, exact definition not given; deaths

attributed to tuberculosis counted as $\begin{array}{ll}\text { Vijay et al }{ }^{\text {w10 }} & \text { New and previously treated, DOTS cured; HIV } \\ \text { not reported; tested for drug susceptibility, but }\end{array}$

$178 \quad$ Death and lost to

$132(74)$

recurrence not given by drug resistance

Thomas et al ${ }^{\text {w11 }}$ New, DOTS cured; HIV not reported; tested for

follow-up

18.0)

Current and previous health status assessed at single patient
bacteriology

drug susceptibility among subset; data

$534 \quad$ Death and lost to

$503(94)$

62, 12.3 (9.6 to

Patients seen at 6

inadequately reported

Daily regimen with

罗 streptomycinf:

Singapore New, fully susceptible, negative bacteriology a

Tuberculosis treatment end; excludes patients who missed

Service/British 14 days treatment in intensive phase or

Medical Research 4 weeks overall; not tested for HIV

follow-up

15.5)

Median 29 months High 


\begin{tabular}{|c|c|c|c|c|c|c|c|c|}
\hline $\begin{array}{l}\text { DOTS regimen, } \\
\text { study }\end{array}$ & Description of patients* & No of patients & $\begin{array}{l}\text { Reasons for } \\
\text { exclusion from } \\
\text { recurrence } \\
\text { analysis }\end{array}$ & $\begin{array}{l}\text { No }(\%) \text { of patients } \\
\text { assessed for } \\
\text { recurrence }\end{array}$ & $\begin{array}{l}\text { No, } \%(95 \% \mathrm{Cl}) \text { of } \\
\text { patients with } \\
\text { recurrent } \\
\text { tuberculosis })\end{array}$ & Assessment and definition of recurrence & $\begin{array}{l}\text { Duration of } \\
\text { follow-up after } \\
\text { treatment (range) }\end{array}$ & $\begin{array}{l}\text { Quality rating } \\
\text { (follow-up) }\end{array}$ \\
\hline $\begin{array}{l}\text { British Medical } \\
\text { Research } \\
\text { Councill }^{\mathbf{1 5} \text { w16 }}\end{array}$ & $\begin{array}{l}\text { New, negative culture at treatment end; } \\
\text { susceptible to all drugs; not tested for HIV }\end{array}$ & 197 & $\begin{array}{l}\text { Death, prolonged } \\
\text { treatment, and } \\
\text { lost to follow-up }\end{array}$ & $166(84)$ & 4, 2.4 (0.7 to 6.1$)$ & $\begin{array}{l}\text { Patients seen monthly in first year and every } \\
3 \text { months thereafter; } \geq 2 \text { positive cultures } \\
\text { obtained at monthly intervals within } 3 \text { months }\end{array}$ & 24 months & Poor \\
\hline $\begin{array}{l}\text { British Thoracic } \\
\text { Societyw1-w3 }\end{array}$ & $\begin{array}{l}\text { New, negative culture at treatment end; not } \\
\text { tested for HIV; not tested for drug susceptibility }\end{array}$ & 146 & $\begin{array}{l}\text { Death, prolonged } \\
\text { treatment, and } \\
\text { lost to follow-up }\end{array}$ & $119(82)$ & $2,1.7(0.2$ to 5.9$)$ & $\begin{array}{l}\text { Patients seen at } 2 \text { month intervals in first year } \\
\text { and every } 3 \text { months thereafter; }>1 \text { positive } \\
\text { culture within } 4 \text { months at least } 2 \text { weeks apart } \\
\text { or diagnosed on radiography }\end{array}$ & 36 months & Poor \\
\hline Malkin et al ${ }^{\mathrm{w} 17}$ & $\begin{array}{l}\text { New and previously treated, treatment success } \\
\text { (not defined); HIV negative; not tested for drug } \\
\text { susceptibility }\end{array}$ & NA & $\begin{array}{l}\text { Death and lost to } \\
\text { follow-up }\end{array}$ & $232(\mathrm{NA})$ & $13,5.6$ (3.0 to 9.4$)$ & $\begin{array}{l}\text { Patients evaluated } 12 \text { months after treatment; } \\
\text { positive sputum smear }\end{array}$ & 12 months & Poor \\
\hline $\begin{array}{l}\text { Mohanty and } \\
\text { Dhamgaye }^{\text {w18 }}\end{array}$ & $\begin{array}{l}\text { New, smear negative at treatment end; HIV } \\
\text { negative; not tested for drug susceptibility }\end{array}$ & 17 & $\begin{array}{l}\text { None (no deaths } \\
\text { reported) }\end{array}$ & $17(100)$ & $1,5.9(0.2$ to 28.7$)$ & $\begin{array}{l}\text { Patients seen at } 3 \text { and } 12 \text { months after } \\
\text { treatment; positive sputum smear }\end{array}$ & 24 months & High \\
\hline \multicolumn{9}{|l|}{$\begin{array}{l}\text { Intermittent } \\
\text { continuation } \\
\text { phase regimen } \\
\text { with } \\
\text { streptomycin }\end{array}$} \\
\hline $\begin{array}{l}\text { Singapore } \\
\text { Tuberculosis } \\
\text { Service/British } \\
\text { Medical Research } \\
\text { Council }^{\text {w19 w20 }}\end{array}$ & $\begin{array}{l}\text { New, drug susceptible, negative culture at } \\
\text { treatment end; excludes patients who missed } \\
\geq 1 \text { drugs for } 2 \text { weeks of intensive phase or } \\
6 \text { weeks overall or otherwise had treatment } \\
\text { regimen changed; not tested for HIV }\end{array}$ & 102 & $\begin{array}{l}\text { Death and lost to } \\
\text { follow-up }\end{array}$ & 96 (94) & $2,2.1(0.3$ to 7.3$)$ & $\begin{array}{l}\text { Patients seen at } 3 \text { month intervals in first year, } \\
\text { every } 3 \text { months to } 30 \text { months and every } \\
6 \text { months thereafter; } \geq 2 \text { positive cultures } \\
\text { obtained at monthly intervals within } 3 \text { months }\end{array}$ & 60 months & High \\
\hline $\begin{array}{l}\text { Singapore } \\
\text { Tuberculosis } \\
\text { Service, }{ }^{\text {221 }} \mathrm{Teo}^{\mathrm{w} 22}\end{array}$ & $\begin{array}{l}\text { New, drug susceptible, negative bacteriology } \\
\text { at treatment end, and receiving treatment } \\
\text { regimen as separate drugs; excludes patients } \\
\text { who missed }>1 \text { week in first month, }>2 \text { weeks in } \\
2 \text { months, or } 6 \text { weeks overall; not tested for HIV }\end{array}$ & 47 & $\begin{array}{l}\text { None (no deaths } \\
\text { reported) }\end{array}$ & $47(100)$ & $0,0(0.0$ to 7.5$)$ & $\begin{array}{l}\text { Patients seen monthly in first year and every } \\
3 \text { months thereafter; } \geq 2 \text { positive cultures } \\
\text { obtained at monthly intervals within } 3 \text { months }\end{array}$ & 18 months & High \\
\hline \multicolumn{9}{|l|}{$\begin{array}{l}\text { Intermittent } \\
\text { regimen with } \\
\text { streptomycintt: }\end{array}$} \\
\hline Cao et al ${ }^{\mathrm{w} 23}$ & $\begin{array}{l}\text { New, two negative smears at or near end of } \\
\text { treatment; HIV not reported; not tested for drug } \\
\text { susceptibility }\end{array}$ & 306 & None & $306(100)$ & $10,3.3$ (1.6 to 5.9$)$ & $\begin{array}{l}\text { Patients seen every } 6 \text { months after treatment } \\
\text { end; positive sputum smear; deaths without } \\
\text { positive smear not considered recurrence }\end{array}$ & 24 months & High \\
\hline Tam et al ${ }^{\text {l24-w26 }}$ & $\begin{array}{l}\text { New, completed trial treatment excludes } \\
\text { rifampicin resistant cases; not tested for HIV }\end{array}$ & NA & $\begin{array}{l}\text { Death and lost to } \\
\text { follow-up }\end{array}$ & $172(\mathrm{NA})$ & 7, 4.1 (1.7 to 8.2$)$ & $\begin{array}{l}\text { Patients seen every } 6 \text { months after treatment } \\
\text { end; positive culture or diagnosed on } \\
\text { radiography }\end{array}$ & $\begin{array}{c}\text { Median } 31 \text { months } \\
(6-48)\end{array}$ & Poor \\
\hline
\end{tabular}

NA=not available.

*DOTS cured refers to patients with negative sputum bacteriology (either smear or culture) at or near end of treatment and on one previous occasion. DOTS treatment completed refers to patients that have completed treatment without bacteriology results and without evidence of treatment failure. DOTS treatment success is defined as categories of cured and treatment completed combined.

†Isoniazid, rifampicin, pyrazinamide, and ethambutol daily for two months followed by isoniazid and rifampicin daily for four months.

łlsoniazid, rifampicin, pyrazinamide, and ethambutol daily for two months followed by three doses of isoniazid and rifampicin weekly for four months.

§Three doses of isoniazid, rifampicin, pyrazinamide, and ethambutol weekly for two months followed by three doses of isoniazid and rifampicin weekly for four months.

Ilsoniazid, rifampicin, pyrazinamide, and streptomycin daily for two months followed by isoniazid and rifampicin daily for four months.

**Isoniazid, rifampicin, pyrazinamide, and streptomycin daily for two months followed by three doses of isoniazid and rifampicin weekly for four months.

t†Three doses of isoniazid, rifampicin, pyrazinamide, and streptomycin weekly for two months followed by three doses of isoniazid and rifampicin weekly for four months. 
disease, early response to therapy, and total amount of chemotherapy (varying by dose, duration, or intermittency) were consistent predictors of relapse, concluding "more extensive disease requires more treatment, and the fewer total doses, the higher the risk that treatment will prove inadequate." ${ }^{.17}$

Overall, potential contributors to recurrent tuberculosis after successful treatment include shorter total durations of treatment (particularly rifampicin), poor adherence during treatment (mainly during the intensive phase), use of fewer than three drugs in the intensive phase, greater disease severity and cavitation, high bacterial load, smoking, being male, the presence of concomitant disease, being underweight, and infection with HIV. ${ }^{151618-21 w 11 \text { w26 }}$ Far from being rare, greater disease severity, difficulties with adherence, and the presence of concomitant diseases are all commonplace in settings with a high burden of tuberculosis, which commonly are characterised by poverty, malnutrition, high rates of HIV infection, and poor access to health care. The differences in disease recurrence across the included studies might be explained by the setting itself along with the exclusion from some studies of patients with the factors most likely to contribute to recurrent disease.

Direct observation - whether daily or three times weekly—is particularly difficult, as it typically requires weak patients to expend time, energy, and money to attend health centres regularly, over long periods. In practice, when distance or difficult terrain present obstacles, direct observation of all doses is unlikely to be occurring, therefore in such settings 100\% adherence is also unlikely, even among patients not classified as defaulting. Measures taken to optimise adherence and support patients receiving treatment may well be important influences on later disease recurrence.

\section{Study limitations}

The main limitations to this review are twofold: the small number of studies located and their extreme heterogeneity. The heterogeneity precludes a more detailed analysis that might explain differences in tuberculosis recurrence after successful treatment. At the same time the features that emerge as limitations for the review, together with the variation in disease recurrence reported, are themselves the review's key findings and underpin our call for more detailed evaluation of functioning tuberculosis programmes in high burden settings.

Only one study differentiated true relapse from reinfection with a different $M$ tuberculosis strain after successful treatment. This study among South African miners found that most recurrences among HIV negative patients were due to relapse. ${ }^{\mathrm{w} 5 \mathrm{w} 6}$ Reinfection has been reported to account for up to $77 \%$ of disease recurrences, however, depending on the prevalence of tuberculosis in the community and the prevalence of HIV infection. ${ }^{822}$ The extent to which reinfection contributes to the proportions of disease recurrence identified in this review is therefore unclear.
The lack of data on tuberculosis recurrence from developed countries for purposes of comparison might also be considered a limitation. Although several studies reported tuberculosis recurrence and even differentiated between relapse and reinfection from developed nations such as the United States, in general these studies report outcomes after a range of nonstandardised regimens or use twice weekly intermittent regimens ${ }^{2223}$ and are therefore not directly comparable to those in this review. It is, however, recognised that recurrent tuberculosis may be important in such settings; the guidelines for tuberculosis treatment from the American Thoracic Society recommend that treatment be extended by several months for those with cavitary disease and slow bacteriological conversion, defined as at high risk of relapse after treatment. ${ }^{24}$ Because treatment is often individualised in resource rich settings, it is difficult to compare tuberculosis recurrence in such settings with the use of standardised regimens under the DOTS strategy in developing nations.

\section{Implications of high tuberculosis recurrence}

At present the effectiveness of interventions in controlling tuberculosis is determined by end of treatment outcomes and estimates of case detection. Countries that implement DOTS normally report patient numbers and end of treatment outcomes annually to WHO. These figures are used to assess progress in tuberculosis control and to predict changes in incidence and prevalence. ${ }^{45}$ The global targets set for tuberculosis control are to detect $70 \%$ of new sputum smear positive cases and to successfully treat $85 \%$ of these cases. ${ }^{25}$ Mathematical modelling suggests that achievement of the targets will precipitate an overall annual $6 \%-7 \%$ reduction in tuberculosis incidence. ${ }^{26}$ If, however, disease recurrence is substantial, current end of treatment targets may be too low to bring about the predicted declines in incidence.

The rise of multidrug resistant tuberculosis and extensively drug resistant tuberculosis have prompted renewed calls for more effective drugs and newer shorter treatment regimens for tuberculosis. ${ }^{2728}$ The results presented here suggest that any new regimens should undergo not only the rigorous clinical trials required for approval of new drugs and regimen combinations but also be trialled under routine programmatic conditions. As well, these evaluations should extend beyond the end of treatment and, ideally, not only differentiate between relapse and reinfection but also consider the complex implications of coinfection with HIV.

Globally, the incidence of tuberculosis is continuing to increase and is expected to reach 150 per 100000 by 2015, representing more than 10 million new cases a year. ${ }^{4}$ Although the increase in tuberculosis case numbers is being fuelled by the HIV epidemic in Africa, factors such as poor case detection, a selective focus on smear positive patients, and, potentially, recurrent disease may be instrumental in Africa and 


\section{WHAT IS ALREADY KNOWN ON THIS TOPIC}

WHO recommends that patients newly diagnosed with pulmonary tuberculosis be given a short course of treatment for six months, daily or intermittently, through the DOTS strategy

A proportion of patients redevelop disease after treatment stops; tuberculosis recurrence is a useful indicator of treatment efficacy

\section{WHAT THIS STUDY ADDS}

A limited number of studies have assessed tuberculosis recurrence after successful treatment The wide variation in recurrence rates suggests that treatment regimens recommended under DOTS may not be universally successful

elsewhere. The implementation of the DOTS strategy has undoubtedly improved the outcomes for many millions of patients. However, treatment regimens that can only produce good outcomes reliably under "ideal" conditions may be of limited use in high burden settings, where challenges for the provision of even basic health services are manifold and complex. Research is urgently needed to determine the most effective approaches to tuberculosis control in the new millennium.

Contributors: HSC conceived the study and is guarantor. All three authors contributed to the drafting of the manuscript.

Funding: HSC was supported by an Australian National Health and Medical Research Council PhD scholarship.

Competing interests: None declared.

Ethical approval: Not required.

Provenance and peer review: Not commissioned; externally peer reviewed.

1 WHO. WHO report on the tuberculosis epidemic, 1995. Stop TB at the source. Geneva: WHO, 1995. Report No WHO/TB/95.183.

2 WHO. The stop TB strategy, Building on and enhancing DOTS to meet the TB-related millennium development goals . Geneva: WHO, 2006. Report No WHO/HTM/STB/2006.37.

3 Styblo K. Overview and epidemiological assessment of the current global tuberculosis situation: with an emphasis on tuberculosis control in developing countries. Bull Int Union Tuberc Lung Dis 1988;63:39-44.

4 WHO. Global tuberculosis control, surveillance, planning, financing . Geneva: WHO, 2007. Report No WHO/HTM/TB/2007.376.

5 Dye C, Watt Cl, Bleed DM, Hosseini SM, Raviglione MC. Evolution of tuberculosis control and prospects for reducing tuberculosis incidence, prevalence, and deaths globally. IAMA 2005;293:2767-75.

6 Huong NT, Duong BD, Co NV, Quy HT, Tung LB, Broekmans JF, et al. Tuberculosis epidemiology in six provinces of Vietnam after the introduction of the DOTS strategy. Int I Tuberc Lung Dis 2006;10:963-9.

7 Chiang CY, Riley LW. Exogenous reinfection in tuberculosis. Lancet Infect Dis 2005:5:629-36.

8 Verver S, Warren RM, Beyers N, Richardson M, van der Spuy GD, Borgdorff MW, et al. Rate of reinfection tuberculosis after successful treatment is higher than rate of new tuberculosis. Am J Respir Crit Care Med 2005;171:1430-5.
9 WHO. Treatment of tuberculosis: guidelines for national programmes . Geneva: WHO,

2003. Report No WHO/CDS/TB/2003.313.

10 Jindani A, Nunn AJ, Enarson DA. Two 8-month regimens of chemotherapy for treatment of newly diagnosed pulmonary tuberculosis: international multicentre randomised trial. Lancet 2004;364:1244-51.

11 Algerian Working Group/British Medical Research Council. Controlled clinical trial comparing a 6-month and a 12-month regimen in the treatment of pulmonary tuberculosis in the Algerian Sahara. Algerian Working Group/British Medical Research Council cooperative study. Am Rev Respir Dis 1984;129:921-8.

12 Balasubramanian VN, Oommen K, Samuel R. DOT or not? Direct observation of anti-tuberculosis treatment and patient outcomes, Kerala State, India. Int I Tuberc Lung Dis 2000;4:409-13.

13 Iseman MD. Good news and not such good news. Int/ Tuberc Lung Dis 1999;3:87.

14 Mwandumba HC, Squire SB. Fully intermittent dosing with drugs for treating tuberculosis in adults. Cochrane Database Syst Rev 2001;(4):CD000970.

15 Chang KC, Leung CC, Yew WW, Ho SC, Tam CM. A nested case-control study on treatment-related risk factors for early relapse of tuberculosis. Am J Respir Crit Care Med 2004;170:1124-30.

16 Korenromp EL, Scano F, Williams BG, Dye C, Nunn P. Effects of human immunodeficiency virus infection on recurrence of tuberculosis after rifampin-based treatment: an analytical review. Clin Infect Dis 2003;37:101-12.

17 Vernon AA, lademarco MF. In the treatment of tuberculosis, you get what you pay for. Am J Respir Crit Care Med 2004;170:1040-2.

18 Benator D, Bhattacharya M, Bozeman L, Burman W, Cantazaro A, Chaisson R, et al. Rifapentine and isoniazid once a week versus rifampicin and isoniazid twice a week for treatment of drug. susceptible pulmonary tuberculosis in HIV-negative patients: a randomised clinical trial. Lancet 2002;360:528-34.

19 Johnson JL, Okwera A, Vjecha MJ, Byekwaso F, Nakibali J, Nyole S, et al. Risk factors for relapse in human immunodeficiency virus type 1 infected adults with pulmonary tuberculosis. Int / Tuberc Lung Dis 1997;1:446-53.

20 Aber VR, Nunn A]. [Short term chemotherapy of tuberculosis. Factors affecting relapse following short term chemotherapy]. Bull Int Union Tuberc 1978;53:276-80

21 Banda H, Kang'ombe C, Harries AD, Nyangulu DS, Whitty CJ, Wirima JJ, et al. Mortality rates and recurrent rates of tuberculosis in patients with smear-negative pulmonary tuberculosis and tuberculous pleural effusion who have completed treatment. Int J Tuberc Lung Dis 2000;4:968-74.

22 Jasmer RM, Bozeman L, Schwartzman K, Cave MD, Saukkonen JJ, Metchock B, et al. Recurrent tuberculosis in the United States and Canada: relapse or reinfection? Am J Respir Crit Care Med 2004;170:1360-6.

23 Dutt AK, Moers D, Stead WW. Short-course chemotherapy for tuberculosis with mainly twice-weekly isoniazid and rifampin. Community physicians' seven-year experience with mainly outpatients. Am J Med 1984;77:233-42.

24 Blumberg HM, Burman WJ, Chaisson RE, Daley CL, Etkind SC, Friedman LN, et al. American Thoracic Society/Centers for Disease Control and Prevention/Infectious Diseases Society of America: treatment of tuberculosis. Am J Respir Crit Care Med 2003;167:603-62.

25 Dye C, Maher D, Weil D, Espinal M, Raviglione M. Targets for global tuberculosis control. Int J Tuberc Lung Dis 2006;10:460-2.

26 Elzinga G, Raviglione MC, Maher D. Scale up: meeting targets in global tuberculosis control. Lancet 2004;363:814-9.

27 Raviglione M. XDR-TB: entering the post-antibiotic era? Int J Tuberc Lung Dis 2006;10:1185-7.

28 Hargreaves S. Existing tuberculosis drugs may hold the key to shorter treatment. Lancet Infect Dis 2007;7:309.

Accepted: 10 December 2007 